\title{
Reuse of Spanish civil war air-raid shelters in Alicante: the R46 Balmis and R31 Seneca shelter
}

\author{
A. B. González Avilés, M. I. Pérez Millan \& A. L. Rocamora Ruiz \\ Building Constructions Department, University of Alicante, Spain
}

\begin{abstract}
More than a hundred public air-raid shelters were constructed beneath Alicante during the Spanish Civil war. Their architectural uniqueness and humanitarian purpose render these shelters a tangible testament to our recent history. The Alicante Municipal Archives hold reports written by technicians who inspected the shelters in the 1940s, which were subsequently included in the Special Plan for public shelters in 1953. Half a century later, in 2003, information on the airraid shelters was included in another Special Plan aimed at protecting Alicante's archaeological heritage.

Thanks to the work of the Municipal Heritage Conservation unit (COPHIAM) and the Special Protection Plan for Urban Archaeology (PEPA), the exact or approximate locations were identified for almost $90 \%$ of the shelters known to have existed.

This paper describes interventions in two of these architectural spaces using advanced museology techniques. The first concerns air-raid shelter R46, located in the Plaza del Dr. Balmis in the city centre. This was built in 1938, and is rectangular with two entrances. The second is air-raid shelter R31, located in the Plaza Séneca.
\end{abstract}

Keywords: air-raid shelter, Spanish Civil War, Alicante, architectural heritage.

\section{Introduction}

During the Spanish Civil War, more than one hundred of air-raid shelters were hastily constructed $[1,2]$ in Alicante to protect the civilian population. "By the beginning of 1937, Alicante already had several such shelters" [3]. Rapidly built with few resources, they were necessarily constructed without previous planning. 
Certainly, no documentary evidence remains of any plans that might have been made [4-6].

The Municipal Archives of Alicante hold a 1945 document concerning demolition of air-raid shelters located in public areas [7]. In the 1950s, municipal experts drew up a Special Plan of Public Shelters containing a detailed documentary record of the shelters known to exist.

In 2003, members of the municipal historic and artistic heritage conservation unit (Spanish initials: COPHIAM), led by archaeologist Pablo Rosser, drew up a series of individual records for a total of 94 air-raid shelters, a project conducted within the framework of the Special Plan for Archaeological Protection (Spanish initials: PEPA) under the authority of the Municipal Board of Culture, the Municipal Board of Housing (RACHA Plan Management Office) and the Department of Finance (Technical Building Department) of Alicante City Council. These records incorporated documents from the 1940s and 1950s, as well as geographical, town planning, cultural and conservation information for each individual air-raid shelter, and a description of the archaeological remains. Other examples of protection records include those of commemorative monuments associated with the Spanish Civil War, such as the Monument to the Fallen at Vega Baja, in Paraje Agua Amarga and the Cross to the Fallen, located in Plaza de Calvo Sotelo, between Paseo de Soto and Avenida Dr. Gadea.

In March 2013, Alicante City Council was able to confirm the exact location and some of the entrances to four of the Spanish Civil War air-raid shelters following a ground-penetrating radar study of the area to obtain an x-ray of the subsurface. Specifically, shelters were detected under the stairway at Jorge Juan high school, beneath the intersection between Avenida General Marvá and Avenida Benito Pérez Galdós, under Poeta Quintana and in Avenida Dr. Gadea, opposite the Casa de las Brujas.

In October 2013, urban re-development works in the Plaza Séneca uncovered a Civil War air-raid shelter in a good state of preservation, the R31 shelter. The City Council modified its project for re-developing the square to include renovation of the shelter, to render it accessible to visitors. The first entrance located to the shelter was a small square air vent which was barely large enough for one person to enter through; however, two stairway entrances were subsequently located.

Shortly after the R31 air-raid shelter was discovered in the Plaza Séneca, redevelopment works at the Plaza del Doctor Balmis in November 2013 revealed the entrance to another Spanish Civil War shelter built under this public area. This was the R46 air-raid shelter, an underground site with a vaulted ceiling. It was divided into various galleries that on first inspection (pending archaeological excavation) were found to preserve some stone benches and one of the lamps.

In 2014, Alicante City Council's Department of Urban Image proposed that a preliminary project should be drawn up as a master plan to coordinate all heritage related to the air-raid shelters (1936-39), which were considered a cultural asset that should be used to create several museums, opening them to the public, providing a visitor reception area and installing signage for the shelters situated along visitor routes. This was combined with Alicante's other 


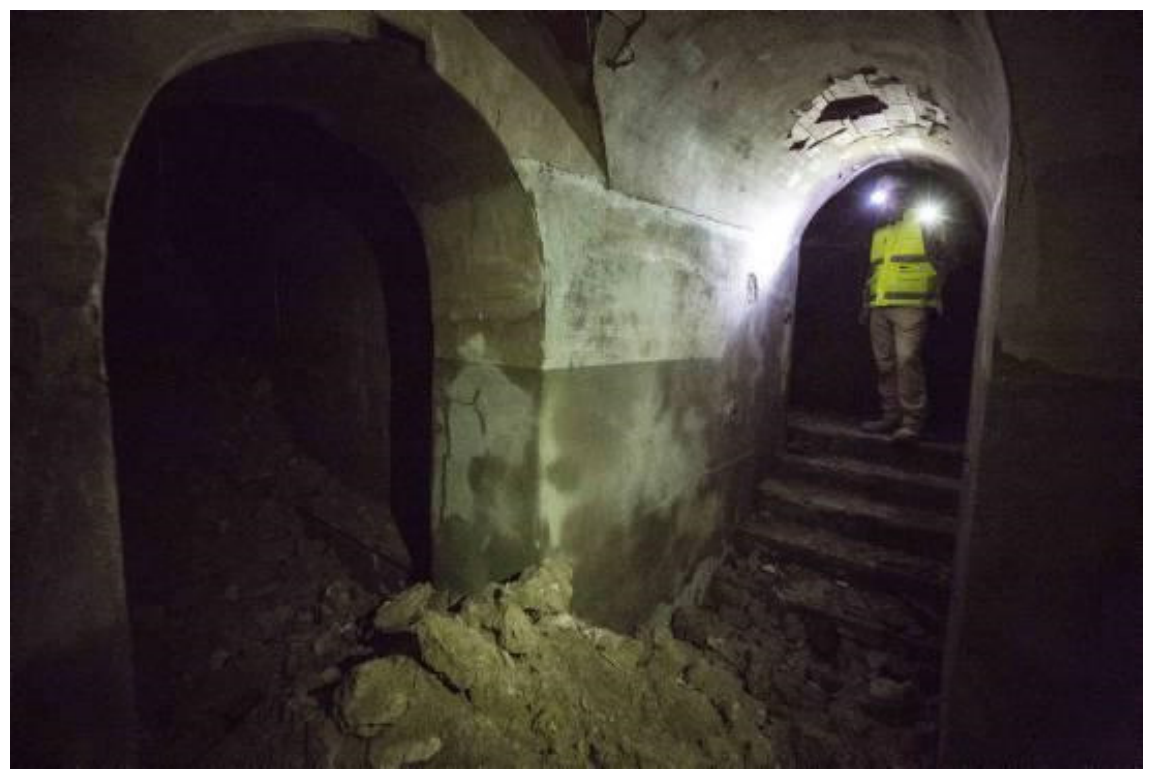

Figure 1: Interior of the R46 shelter beneath the Plaza del Doctor Balmis (source: Diario Información).

attractions, creating a complex package that comprised the development of themed visitor routes, restored architectural remains open to the public and a visitor reception centre that explained these heritage sites in their particular and global context.

\section{Methodology}

In order to place the architectural intervention in context, a map of the city of Alicante was drawn up based on the one initially created by COPHIAM/PEPA. This identified shelters that, due to their commercial and/or cultural location in the city or their present condition, were considered suitable for conversion into museums that could be incorporated into the project. Information sheets were written for each of the shelters listed below, which served as a basis for individual tourist leaflets:

- Code 280. Plaza de Séneca R31;

- Code 295. Plaza Balmis R46;

- Code 263. Pozos de Garrigós [8];

- $\quad$ Code 320. La Cantera (La Británica) [9];

- Spanish Civil War Museum (on the site of the former Alicante Port offices). 


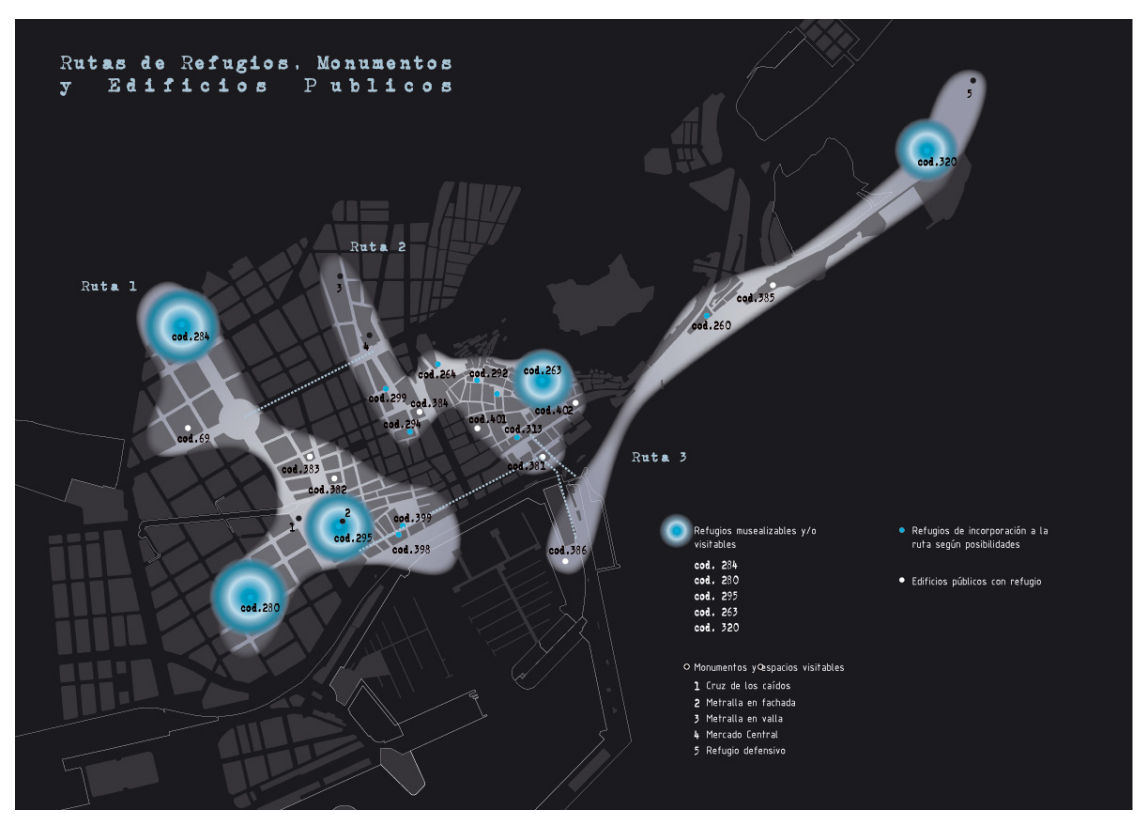

Figure 2: Map of Alicante with the proposed visitor routes, monuments and public buildings.

The map in Figure 2 shows various historic sites that are either monuments or defensive/offensive constructions related to the period 1936-39. It also depicts sites where shrapnel scars are still visible in building façades. These include buildings in the Plaza del Doctor Balmis, the wall of the La Lonja car park on Calle Capitán Segarra and the monument to Canalejas. Besides the shelters, the visitor routes proposed also include many public buildings with areas used as airraid shelters in their basements, and other buildings which were used as makeshift shelters because of their physical features or logistic or strategic nature. Other sites include the trenches located in the Serra Grossa, a machine gun pillbox in the La Ereta park and monuments in memory of all those who fell in the Spanish Civil War, such as the Los Almendros concentration camp in the area of La Goteta.

The map depicts the following sites:

- Air-raid shelters suitable for conversion into museums and/or visitor access;

- Air-raid shelters suitable for signage;

- Monuments and/or areas suitable for visitor access;

- Public buildings with air-raid shelters.

Three different areas have been defined according to the urban context of the shelters (Figure 2). The table below lists the three routes and the historic sites they each include (Table 1). 
Table 1: $\quad$ Proposed routes and historic sites.

\begin{tabular}{|c|c|}
\hline \multicolumn{2}{|c|}{$\begin{array}{l}\text { Route 1: Provincial Council/19th century expansion district and historic } \\
\text { city centre }\end{array}$} \\
\hline \multirow{2}{*}{$\begin{array}{l}\text { Air-raid shelters suitable for } \\
\text { conversion into museums } \\
\text { and/or visitor access }\end{array}$} & Code 280. R31. Plaza Séneca \\
\hline & Code 295. R46. Plaza Balmis \\
\hline \multirow[t]{8}{*}{$\begin{array}{l}\text { Air-raid shelters suitable for } \\
\text { signage }\end{array}$} & $\begin{array}{l}\text { Code 284. Stairway on Avenida General } \\
\text { Marvá }\end{array}$ \\
\hline & Code 215. Maestro Bretón \\
\hline & Code 283. Avenida General Marvá \\
\hline & Code 304. Paseo de Soto \\
\hline & Code 306. Avenida Doctor Gadea \\
\hline & $\begin{array}{l}\text { Code 398. Calle García Hernández (now } \\
\text { Calle San Fernando) }\end{array}$ \\
\hline & Code 314. Casino \\
\hline & Code 124. Plaza Montañeta \\
\hline \multirow[t]{4}{*}{$\begin{array}{l}\text { Monuments and/or areas } \\
\text { suitable for visitor access }\end{array}$} & $\begin{array}{l}\text { 1. Monument: Cross to the Fallen (Cruz de } \\
\text { los Caídos) }\end{array}$ \\
\hline & $\begin{array}{l}\text { 2. Shrapnel in building façade, Plaza del } \\
\text { Doctor Balmis }\end{array}$ \\
\hline & 3. Shrapnel in the Canalejas monument \\
\hline & $\begin{array}{l}\text { 4. Shrapnel at the former Alicante port } \\
\text { offices }\end{array}$ \\
\hline \multirow{4}{*}{$\begin{array}{l}\text { Public buildings with air-raid } \\
\text { shelters }\end{array}$} & Code 399. Telegraph office \\
\hline & Code 69. Provincial Council of Alicante \\
\hline & Code 382. Treasury Department \\
\hline & Code 383. Provincial Governor's Office \\
\hline \multicolumn{2}{|c|}{ Route 2: Market-Historic Centre } \\
\hline $\begin{array}{l}\text { Air-raid shelters suitable for } \\
\text { conversion into museums } \\
\text { and/or visitor access }\end{array}$ & Code 263. Pozos de Garrigós \\
\hline \multirow{7}{*}{$\begin{array}{l}\text { Air-raid shelters suitable for } \\
\text { signage }\end{array}$} & Code 400. Bank of Vizcaya \\
\hline & Code 294. Capuchinas \\
\hline & Code $264 . \mathrm{C} / 1^{\circ}$ de mayo \\
\hline & Code 292. Plaza de Quijano (Plaza Carmen) \\
\hline & Code 293. Calle Villavieja, Jorge Juan \\
\hline & Code 262. Calle Lucentum \\
\hline & Code 261. Calle Mare Nostrum \\
\hline \multirow{4}{*}{$\begin{array}{l}\text { Monuments and/or areas } \\
\text { suitable for visitor access }\end{array}$} & 5. Shrapnel in the La Lonja car park wall \\
\hline & $\begin{array}{l}\text { 6. Central Market. Commemorative plaque } \\
\text { and showcase for clock and siren }\end{array}$ \\
\hline & 7. Graffiti on the co-cathedral of San Nicolás \\
\hline & $\begin{array}{l}\text { 8. Graffiti and prison cells at Santa Bárbara } \\
\text { Castle }\end{array}$ \\
\hline
\end{tabular}


Table 1: Continued.

\begin{tabular}{|c|c|}
\hline \multicolumn{2}{|c|}{ Route 2: Market-Historic Centre } \\
\hline \multirow{6}{*}{$\begin{array}{l}\text { Public buildings with air-raid } \\
\text { shelters }\end{array}$} & Code 299. Casa de Socorro \\
\hline & Code 125. Market \\
\hline & Code 318. Tabacalera (tobacco factory) \\
\hline & Code 384. Bank of Spain \\
\hline & Code 401. Co-cathedral of San Nicolás \\
\hline & Code 402. Basilica of Santa María \\
\hline \multicolumn{2}{|c|}{ Route 3: Port-Postiguet-Raval Roig and Serra Grossa } \\
\hline $\begin{array}{l}\text { Air-raid shelters suitable for } \\
\text { conversion into museums } \\
\text { and/or visitor access }\end{array}$ & Code 320. Cantera (La Británica) \\
\hline \multirow{3}{*}{$\begin{array}{l}\text { Air-raid shelters suitable for } \\
\text { signage }\end{array}$} & Code 310. Paseito Ramiro \\
\hline & Code 403. Patrimonio Artístico \\
\hline & Code 260. Plaza de Topete \\
\hline \multirow{4}{*}{$\begin{array}{l}\text { Monuments and/or areas } \\
\text { suitable for visitor access }\end{array}$} & 9. Searchlight tower on Mount Benacantil \\
\hline & 10. Defensive shelter \\
\hline & 11. Trenches \\
\hline & 12. Los Almendros concentration camp \\
\hline \multirow{4}{*}{$\begin{array}{l}\text { Public buildings with air-raid } \\
\text { shelters }\end{array}$} & Code 386. Port of Alicante \\
\hline & Code 381. Palas Hotel \\
\hline & Code 313. City Hall \\
\hline & Code 385. The Marina Station \\
\hline
\end{tabular}

\subsection{Case study: Balmis (R46) and Séneca (R31) air-raid shelters}

The first intervention undertaken within the proposal for visitor routes, signage and conversion into museums of Spanish Civil War heritage sites in Alicante (defensiveloffensive constructions and monuments) concerned the shelter located in the Plaza Balmis, followed by the one in the Plaza Séneca.

These interventions consisted of carrying out the work necessary to open the shelters to the public and ensure the safety of visitors. This involved structural work with a view to preventive conservation, and restoration of the shelters in order to "display" them as exhibits.

Funds for the restoration and conversion into a museum of the R46 air-raid shelter were limited, but nevertheless sufficient to repair the finishing and damaged steps, install emergency lighting and ventilation, restore the original overhead wiring (to demonstrate the original layout, but without a current), recreate the scene in two of the four available rooms in the air-raid shelter, and design and install ambient sound and free-standing information panels.

In this project, architectural intervention and visitor information were combined in a hybrid museum proposal aimed at ensuring dialogue and communication with the community and with visitors. 
The goal of the architectural project was to recreate the air-raid shelter as an interpreted artefact, creating a narrative transmitted through sound, an art installation, visual resources and the construction itself.

Burcaw [10] has distinguished between display and exhibit: "an exhibit is a display plus interpretation; or, a display is showing, an exhibit is showing and telling". In this case, exhibition of the architectural object is supported by sound, visual resources and an art installation to facilitate a better understanding.

\subsubsection{The mode and type of exhibition}

The aim of the intervention carried out on both shelters was to create an exhibit that served four roles: symbolic, commercial, historical and aesthetic [11]:

- Symbolic, avoiding any ostentatious presentation of the exhibit. Mainly from the perspective of a political interpretation of a recent conflict that persists in society's subconscious and rapidly awakens the spectator's interest.

- Commercial, as a new cultural asset forming part of a network of Spanish Civil War heritage sites, the discovery of which has clearly aroused social interest.

- Historical, applying contemporary rigour to restore and document heritage as an architectural asset and a means of disseminating knowledge.

- $\quad$ Aesthetic, recreating scenes that help understand the architecture.

Both spatially and temporally, this could be considered a hybrid intervention involving permanent elements (the architectural object) and temporary ones (the art installation, ambient sound and visual resources as a vehicle for interpretation when initially opened to the public, which can quickly be removed and discarded).

In accordance with the nature of the exhibit, the intervention constitutes the type of exhibition that offers the original project for interpretation: the architectural element as exhibit, as an original artefact.

In accordance with the intentional presentation of a thesis statement, a personal approach was adopted to the message and the conceptual and museographic modes - sound, an art installation and the recreation of scenes used to transmit this and facilitate understanding and communication.

In accordance with the variety and density of the content, this is a multipurpose museum that permits different levels of interpretation according to different mentalities, education or age, the goal of which is to convey a very particular vision using very special media and technical and visual structures that summarise the architectural object in a brief visit.

In accordance with the categories or characteristics, the target audience would not perceive this as a didactic exhibition, but rather, in the words of Michael Belcher, as an emotive one [12], since it is a vehicle for recovering and consolidating heritage (see Figure 3). 


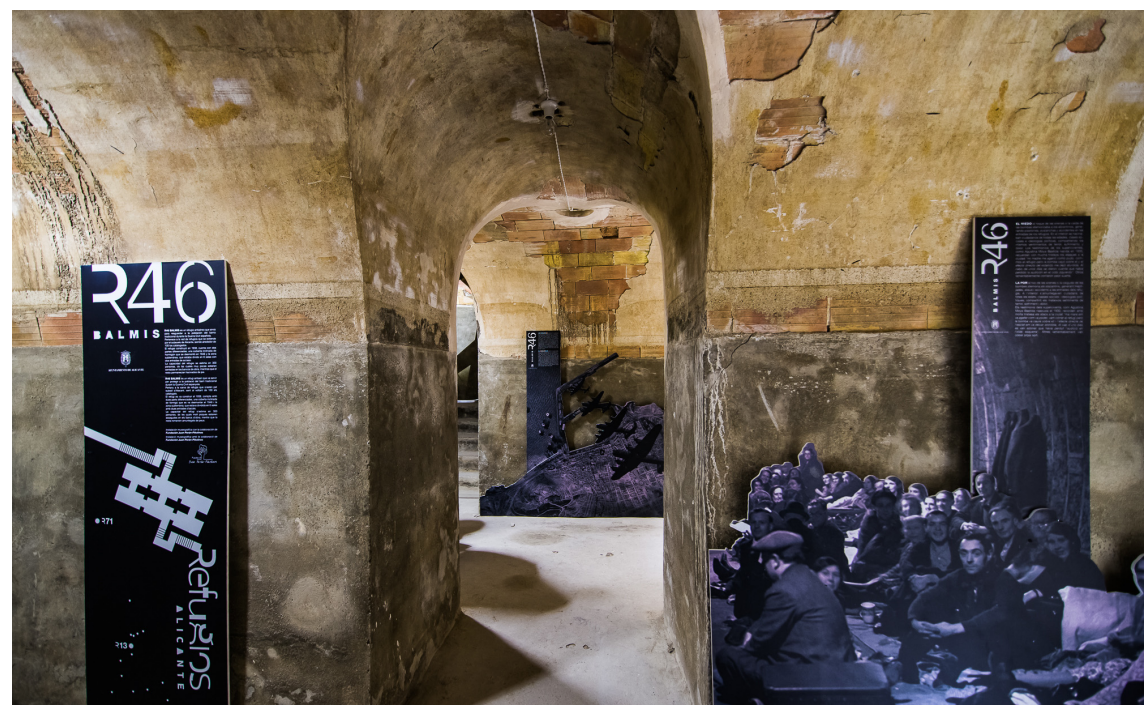

Figure 3: Interior of the R46 Balmis air-raid shelter following transformation into a museum.

\subsubsection{Organisation of space, thought, representation, recreation and narrative}

Design of the artistic scale and recreation was conceived in unison to facilitate a particular vision, interpretation and representation of the air-raid shelter in the Plaza del Doctor Balmis.

Public access to the two rooms is limited by a metal bar, and the dense overcrowding of air-raid shelters during bombing is recreated by means of pairs of shoes distributed in a haphazard but carefully considered fashion on the floor. All of them grey, the shoes convey a "hushed" message about density, a tangible, measured, scientific fact, as well as a psychological message, as an abstract dramatisation of the real situation in an air-raid shelter when in use (see Figure 4).

Both exhibitions apply theatrical concepts such as drama and narrative, which are very close to metaphor and abstraction, but also employ hyper-realistic expression closer to the sculptural works of Antonio Lopez.

The installation in the Balmis air-raid shelter uses a simple communicative design combined with technological media and visuals: a soundtrack composed by Luis Ivars, and information panels that briefly explain the architecture, geometry, use and historical context to visitors.

Theatrical techniques have also been employed through the use of indirect lighting aimed at creating a suggestive atmosphere and thus facilitating a better understanding of the space among visitors. 


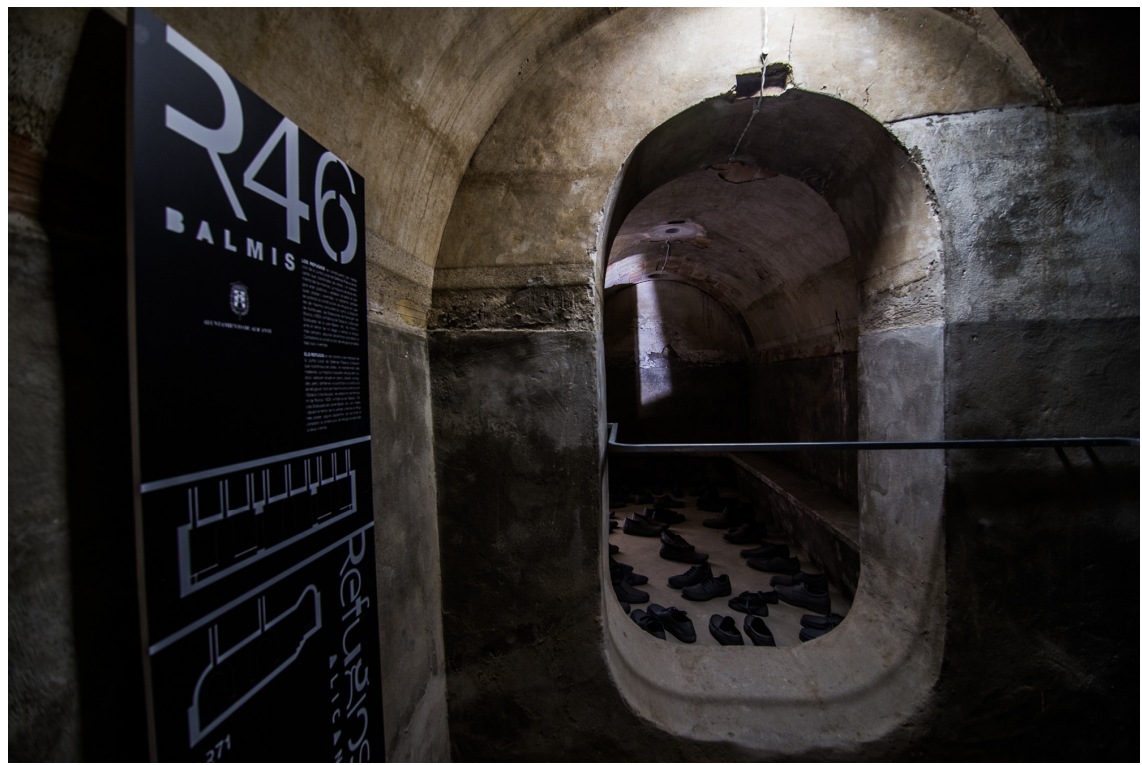

Figure 4: Interior of one of the rooms in the R46 Balmis air-raid shelter following conversion into a museum.

\section{Conclusions}

Consideration of Spanish Civil War air-raid shelters as part of the cultural heritage and architecture of the city of Alicante has led to a project aimed at restoring this defensive architecture that forms part of the city's legacy and history, and that of its inhabitants.

The proposal made in 2014 by Alicante City Council's Department of Urban Image to draw up a preliminary project as a master plan to coordinate all heritage related to the air-raid shelters (1936-1939), which were considered a cultural asset, has made it possible to create various museum spaces and to open the airraid shelters to the public, thus allowing visitors a glimpse of life in the past in Alicante. In line with Santacana Mestre and Martínez Gil [13], the aim has been to use heritage not only in the service of memory, but also as a means communicate, whether science or art or any other area of human knowledge.

The transformation of these architectural spaces into museums and the perceptions stimulated through the use of light, sound, recreation of scenes and visual techniques all transmit fascination and suggestion, facilitating understanding of a particular space at a given historical moment.

\section{References}

[1] Ramos, V. (1972-74). La Guerra Civil, 1936-1939 en la Provincia de Alicante. 3 Vols. Ediciones Biblioteca Alicantina. 
[2] Cutillas Bernal, E. (2003). Crónica de la muy ilustre ciudad de Alicante. Tomo II, 1936-1999, Alicante, Excmo. Ayuntamiento municipal de Alicante.

[3] Cerdán Tato, E. (1986). "Alicante: la masacre de los Savoia", Canelobre, 6/7. Alicante, Instituto de Cultura Juan Gil-Albert.

[4] Pérez Oca, M. (2005). 25 de Mayo. La tragedia olvidada. San Vicente (Alicante), Editorial Club Universitario.

[5] Capdepón, L. (2006). Alicante Bombardeado. Alicante, Instituto de Cultura Juan Gil-Albert.

[6] Gómez Serrano, E. (2008). Diarios de la guerra civil (1936-1939), Alicante, Universidad de Alicante, Vicerrectorado de Extensión Universitaria (Edición de Beatriz Bustos y Francisco Moreno).

[7] A.M.A., Arm. 19, Leg. 30/3 (1937). Expediente sobre construcción de refugios y reforma de los existentes; A.M.A., Arm. 19 Leg. 30/5 (19371939). Expediente de actas de sesiones extraordinarias del Comité de Defensa Pasiva; A.M.A., Arm. 19 Leg. 30/11 (1938). Expediente sobre proyecto de refugio en la estación de MZA Plano; A.M.A., Arm. 19, Leg. 30/14 (1945). Expediente de demolición de refugios antiaéreos situados en la vía pública; A.M.A., Arm. 19 Leg. 30/17 (1953). Expediente sobre el Plan Especial de refugios; A.M.A., Arm. 19 Leg. 30/18 (1953). Expediente de petición de datos sobre refugio existente en Diputación Provincial; A.M.A., Arm. 19 Leg. 30/21 (1954). Expediente sobre que el arquitecto municipal Miguel López González, Jefe ejecutivo de la fase de refugios de defensa Pasiva Civil de Alicante proceda a la inspección y arreglo de los refugios; A.MA., Arm. 19 Leg 30/23 (1954). Expediente de petición sobre refugios y servicio de extinción de refugios; A.M.A., Arm. 19 Leg. 30/25 (1955). Expediente de solicitudes de vecinos para la utilización de los refugios de los barrios de San Blas y Florida.

[8] Jaen i Urban, G. et al. (1999). Guía de arquitectura de la Provincia de Alicante. Alicante, Biblioteca Virtual Miguel de Cervantes. p. 42.

[9] Aguilar Civera, I. (2006). De la refinería La Británica a la factoría "La Cantera" de Alicante. Editorial Cátedra Demetrio Ribes.

[10] Burcaw, Ellis. (1997). Introduction to museum work. Walnut Creek: Altamira Press, p. 129.

[11] Alonso Fernández, L.; García Fernández, I. (2010). Diseño de exposiciones. Concepto, instalación y montaje. Alianza Forma. pp. 23-40.

[12] Belcher, M. (1994). Organización y diseño de exposiciones, su relación con el museo. Editorial TREA.

[13] Santacana Mestre, J.; Martínez Gil, T. (2013). "Patrimonio, identidad y educación: una reflexión teórica desde la historia”, en Educatio Siglo XXI, Vol. 31, n' 1, pp. 47-60. 